\title{
Indonesian Politicians' Social Media Role in Encouraging Civic Engagement
}

\author{
Alia Azmi \\ Civic Education Department \\ Universitas Negeri Padang \\ Padang, Indonesia \\ alia.azmi@ fis.unp.ac.id
}

\author{
Ike Sylvia, Desy Mardhiah \\ Sociology Department \\ Universitas Negeri Padang \\ Padang, Indonesia
}

\begin{abstract}
Among the fields that benefit from the internet and social media use are political participation and civic engagement. Politicians have long been using social media for their interests including campaigning and communicating with their constituents. On the other hand, civic engagement, which might include political and non-political actions, has been transformed by the internet and social media use that there are specific terms of civic online participation. This research aims to reveal the role of politicians, as public figures, in social media in encouraging civic engagement. This research used qualitative content analysis to reveal messages by politicians in their social media accounts. Politicians are selected based on the number of their followers in the most popular social media platforms; Facebook, Instagram, and Twitter. Therefore, social media posts of three politicians were analyzed; 2014 presidential candidate Prabowo Subianto (most Facebook followers, Bandung mayor Ridwan Kamil (most Instagram followers), and former president Susilo Bambang Yudhoyono (most Twitter followers). The result shows that those politicians use their social media accounts to: (1) inform about their activities, both personal and institution- or party-related; (2) announce public policies; (3) express their opinions on contemporary issues; (d) greet constituents on national holidays; and (e) encourage civic engagement. Most of the contents are merely information about their activities and opinions, and there are few invitations for civic engagement. Further studies on politicians' posts on social media and followers' reaction are needed to reveal a more detailed correlation between the two to propose a better role of politicians in encouraging civic engagement.
\end{abstract}

Keywords - civic engagement; politicians' social media; Prabowo Subianto's Facebook; Ridwan Kamil's Instagram; SBY's Twitter

\section{INTRODUCTION}

The use of social media for politics, campaign, and communications between public figure and followers have been improving since 2010s. Although political figures, such as the former US president Barrack Obama, have long started the political use of social media since before the 2010, the use of social media in politics continue to show impressive growth. Other world leaders now maximize their use of social media to interact with their constituents and non-constituents. Older leader such as US President Donald Trump, with more followers than the younger leaders Canada's Prime Minister Justin Trudeau and France's Emmanuel Macron, get more responses from netizens all over the world due to his controversial policies and comments.

In Indonesia, politicians use of social media gained its momentum when former President Susilo Bambang Yudhoyono (SBY) started his Twitter and Facebook account in 2013, and until now is still the most followed politician in Twitter (as September 2017). His cabinet ministers and oppositions also use the social media, and its use reached a new point again during the 2014 presidential election where candidates Joko Widodo and Prabowo Subianto have their accounts as well as their supporters. These accounts are mostly used for diverging campaign promises as well as personal activities that are aimed at image building [1]. For politicians in office, their social media contents usually include policies, personal activities, parties' activities, comments, opinion, and stories of family/closest circles. The vibrant public debate, particularly in the social media during the presidential election, shows how politicians' social media improve public concerns in politics.

Civic engagement, identified as individual and collective actions to address issues of public concerns to promote the quality of public life, is believed to increase in the digital era. The use of internet and social media contributes to the participation of citizens to do something for their surroundings, other people, and the nation. Ognyanova [2] found that community internet activities promote offline civic engagement and intergroup dialogue in multiethnic societies. Gil de Zúñiga [3] researched the role of digital media use in democratic processes, and found that people's habit of following information on social network sites predicts significantly their civic and political participatory behaviors both online and offline. Global media thinkers see the 2010s protests in the Middle East or Arab Spring to overthrow authoritarian regimes as "the new civic voices" [4], and "connective action" [5], which means a political action stemmed from and organized using the social media, while the world watches the events from faraway through viral posts and hashtags. Other large demonstrations and marches echoed in social media followed all over the world until now, such as the MeToo movement to fight against sexual harassment in late 2017. In Indonesia, online political debates have divided the public in the 2014 presidential election; online provocation sparked protest of former Jakarta governor Ahok for defamation of religion, and 
Yogyakartan youths gather local community actions from social media, which also functions as balancer, reminder, and youth movement driver [6].

\section{LITERATURE REVIEW}

\section{A. Social Media}

Social media are models of dialogic transmission systems that provide information, thought, and ideas to many receivers [7]. It can also be referred to interactive internet-based applications where the contents are generated by users who have profiles and form online social networks by connecting users' profile with other individuals or groups [8]. Boyd and Ellison define social network sites as web-based services that allow individuals to create a public or semi-public profile, choose a list of other users to connect with, and view and traverse their connections and those made by others. Social media, among others, implement this social network sharing features [9].

Defining social media requires the understanding of what social is about. Although the media is a technological product, it provides interaction and deals with social relations and human activities in complex ways [10]. Most social media technologies originated before 2005 , but only popular since at the second half of the decade, showing radical change in the internet economy and capital accumulation [10]. Katz [11] define social media as "digital multiway channels of communication among people and between people and information resources and which are personalized, scalable, rapid, and convenient".

\section{B. Civic Engagement}

There term civic engagement or civic participation was popularized by Robert Putnam in 1995. Although he did not literally define civic engagement, he concerned about the disengagement of Americans in politics and government, religious affiliation, non-political group membership, and volunteering [12]. Encyclopedic sites such as American Psychological Association defines civic engagement as "individual and collective actions designed to identify and address issues of public concern" [13]. Encyclopedia Britannica defines civic engagement as a broad set of practices and attitudes of involvement in social and political life that converge to increase the health of a democratic society" [14]. Adler and Goggin attempted a comprehensive look to define civic engagement, from specific to broad definitions, from informal/private individual action to formal/public collective action, and they proposed a definition of civic engagement as a description of "how an active citizen participates in the life of a community in order to improve conditions for others or to help shape the community's future" [15]. Civic engagement is expected to make a difference by combining the knowledge, skills, values, and motivation in order to promote the quality of live in a community [16]. In this article the term civic engagement is interchangeably used with civic participation, as when it comes to media use in the society, "online civic participation is more commonly used in scientific articles and literatures.
Schlozman, Verba, and Brady proposed three justifications to concern about civic engagement; the development of individuals' capacities, the good implications for democracy, and the shift of "emphasis from shared community interests to the conflicting interests of individuals and groups and focuses on equal protection of interests" [17].

The term civic engagement sometimes overlaps with political participation. Based on the definition above, civic engagement covers a broader range of activities, both political and non-political, for the better societies, while political participation involves individual and group participation related to the state and the government. Keeter [18] indicates civic engagement in three main categories; civic indicators, electoral indicators, and political voice indicators, which are then divided to 19 more detailed indicators such as participation in fund-raising run/walk/ride, regular voting, and contacting officials. In this research, the three main indicators were used to indicate civic participation.

In Indonesia, the term civic participation or engagement (partisipasi kewargaan/keterlibatan warga) is only recently used in the mass media, while it is still rare in academic discussion. In civic education, experts and teachers use more of "political participation" term to describe the citizens" involvement in the society, which are almost all political such as voting and expressing opinions. However, this does not mean that Indonesians lack the social engagement for a better society, as this might be discussed in other more popular terms such as kesukarelawanan (volunteering) and gerakan sosial (social movement). Warren [19] and Lussier and Fish [20] argues about Indonesians' high level of civic engagement, where Warren found that in youth's Facebook activities. The increasing use of social media for civic participation makes this research necessary.

\section{Online Civic Participation}

Christian Fuchs uses the term participatory culture to refer to the "involvement of users, audiences, consumers, and fans in the creation of culture and content," particularly in the age of internet where audiences can produce culture themselves such as editing articles on Wikipedia and uploading videos to YouTube, as opposed to the mass media of newspapers, radio, and television where there is only one sender and many recipients [10].

Since the massive use of internet and digital social media, concerns about civic participation arise because both are likely interlinked. However, researchers are not decisive yet about the relationship between the two. Chang Woo-Young argues that Korea's online media functions as an "epicentre of activities" that contributes to the political reform against hegemony, since it facilitates horizontal interactions between the producers and the receivers of messages [21]. This resonates with Zúñiga, et al.'s research about how social network sites increases users' feel of connectedness to the community as well as reciprocity and trust, thus fostering civic and political engagement [3]. Internet activities in a community promotes off-line civic engagement and intergroup dialogue, although disconnected social groups remain excluded from the online engagement, and the elderly as well as lower education and socioeconomic 
groups are less likely to be involved in digital participation [2]. However, Dimitrova suggests that the effects of digital media use on political learning are weak, although the use of certain digital media forms has appreciable effects on political participation [22]. This is not to say that digital media use is useless for civic engagement. Cogburn and Espinoza-Vasquez even suggests that the 2008 Obama campaign in social media helped encouraging grassroots movements and volunteering and continued the strategies to motivate political participation and civic engagement during Obama-Biden terms [23]. Obama's successful digital campaign and civic encouragement can be attributed to the personalization of politics [24,25]. The personalization of politics is a term to describe the increasing importance of individual leaders, instead of groups and parties, in the political arena [26], whereas the public's feeling of connectivity with leaders from their personal point of view in the news has been known to prompt civic engagement [27].

Those previous research have led to the conclusion that the internet and social media use is significant for civic engagement, although still much debated in terms of its benefit for individual improvement in civic engagement. However, few previous research focus on the role of political leaders in encouraging civic engagement online, despite the increasing use of digital media by politicians with significant number of followers, let alone in Indonesia. This article discusses civic engagement messages in Indonesian politicians' social media posts. In broader context, it is expected to hint the role of politicians in encouraging civic engagement.

\section{METHODS}

This study used qualitative content analysis with inductive and deductive approach. First, we selected posts from politicians' social media from August 2017 to October 2017. The politicians' social media are Prabowo Subianto's Facebook fanpage (7 million followers), Ridwan Kamil's Instagram (7 million followers), and Susilo Bambang Yudhoyono's Twitter (9 million followers) per September 2017, because those accounts are the most followed among politicians' in the three popular social media platforms. Second, the text (including photos and videos) are repetitively read and deeply observed to produce the manifest and latent meaning that describes civic engagement activities and encourages individuals and groups to join civic activities, which are based on Ketter's 19 indicators from all the main categories of civic indicators, electoral indicators, and indicators of political voice. The three main categories include social participation for the better society which can be seen from non-political and political activities such as community problem solving as well as supporting a political cause or candidate. Finally, themes are categorized into the explicit or strongest invitation of civic engagement (including word "let's" to join some concrete activities) to the implicit or softest encouragement (no inviting word but showing example of civic engagement indicators).

\section{RESULT AND DISCUSSION}

Keeter's three indicators of civic engagement are shown in Table 1 [18].

\section{TABLE I. KEETER'S CIVIC ENGAGEMENT INDICATORS [18].}

\begin{tabular}{|c|c|}
\hline $\begin{array}{c}\text { Civic } \\
\text { indicators }\end{array}$ & $\begin{array}{l}\text { Community problem solving } \\
\text { Regular volunteering for a nonelectoral organization } \\
\text { Active membership in a group or association } \\
\text { Participation in fund-raising run/walk/ride } \\
\text { Other fund-raising for charity }\end{array}$ \\
\hline $\begin{array}{l}\text { Electoral } \\
\text { indicators }\end{array}$ & $\begin{array}{l}\text { Regular voting } \\
\text { Persuading others to vote for or against a party or } \\
\text { candidate } \\
\text { Displaying campaign buttons, signs, stickers } \\
\text { Campaign contributions, particularly financial } \\
\text { Volunteering for candidate or political organizations }\end{array}$ \\
\hline $\begin{array}{c}\text { Indicators of } \\
\text { political } \\
\text { voice }\end{array}$ & $\begin{array}{l}\text { Contacting officials } \\
\text { Contacting the print media } \\
\text { Contacting the broadcast media } \\
\text { Protesting } \\
\text { E-mail petitions } \\
\text { Written petitions } \\
\text { Boycotting a product } \\
\text { Buycotting (buying a product as an expression of } \\
\text { political opinion) } \\
\text { Canvassing; going door-to-door to support a political } \\
\text { cause or candidate }\end{array}$ \\
\hline
\end{tabular}

The politicians' social media posts were read closely and repetitively to find messages that encourage civic activities according to the 19 indicators.

From 12 posts in Prabowo Subianto's Facebook fanpage, there are five that are considered civic engagement messages, both in encouraging and showing examples.

- August 24 post of pictures of Prabowo with some athletes and officials, captioned "attending the opening ceremony of Pencak Silat round in SEA Games 2017." Next he motivated the athletes in order to make the nation proud. There's no clear invitation to civic engagement here, although he did motivate the athletes. This is considered an example of civic engagement for active membership in a group or association, since Prabowo is the chairman of Ikatan Pencak Silat Indonesia (Indonesia's Pencak Silat Association). Pencak Silat is a martial art of Indonesia.

- September 11 post (without pictures and other media) stated that his party, Gerindra, is concerned about the violence against the Rohingyas. He also addressed the Burmese government to stop violence against the Rohingyas. This is considered a petition to the Burmese government, although he wrote in Indonesian that it is more likely to be addressed to his fellow party members. This is supported by the rest of the message where he also reminded fellow Indonesians to maintain unity in diversity particularly among religious groups to avoid the tragic violence like in Myanmar to happen in Indonesia. The message to fellow Indonesians is not considered encouragement to civic engagement, though, since there's no concrete activity to be done by the public.

- Two posts in September 15 and 17 of pictures of his participation in street protest against violence in Myanmar's Rohingya. Although there's no inviting word, this is an example for protesting, which is an indicator for engagement in political voice. 
- September 19 picture of Prabowo in the middle of a rice field with some people, probably his entourage and local communities. There's no caption, but it can be interpreted that Prabowo was showing his concern in rice farming, as he is the chairman of Himpunan Kerukunan Tani Indonesia, a social organization in the field of agriculture and rural development. This shows active membership in a group or association.

- October 1 post of pictures of a political campaign; crowd gathered in front of a stage with Prabowo on it, and many Gerindra flags. The caption addressed West Nusa Tenggara residents to support Gerindra's candidates for 2018 gubernatorial election TGH Ahyar Abduh and H Mory Hanafi. "Supporting a candidate" clearly means electoral engagement, although it might be categorized into almost all detailed indicators; regular voting, persuading others, displaying buttons, signs, stickers, campaign contributors, and volunteering. The remaining message mentioned about guarding fair and clean democratic process.

Meanwhile, from 61 Ridwan Kamil' Instagram's posts, there are seven messages of encouragement and examples of civic engagement:

- Pictures of a mountain and evacuees, focusing on children and elderly, on Sept 28, captioned about an invitation to donate to Bali's Mount Agung eruption evacuees through crowd-funding site kitabisa.com.

- On some Sunday (in this research period on September 23 and 30), he posted a picture of people praying together, the caption says an invitation to Subuh prayer together at the mosques. There's an address of a mosque where he will attend the Subuh prayer. He also suggested the Christians to attend Sunday services. The prayer and services might be personal religious activities, but some social activities start from discussion at religious gatherings such as at the mosque and Sunday services, therefore this post is interpreted as a soft invitation to engage in civic activities.

- October 7 post of a cartoon poster picturing three people in front of a garbage can and one of them holding a broom. The caption says an invitation to Bandung and West Java residents to clean up the city. There's also an internet link to register as volunteers for "Clean Up Jabar Day."

- October 8 post of a collated picture. The first picture is another cartoon poster picturing a man beside a car. The second and third are pictures of some people around a car and a truck. The caption says an invitation to be "transport volunteers" to transport residents during city transport (bus and angkot minivan) protest on Oct 1013. The protest turned out to be cancelled.

- October 8 post of screenshot news on Pangandaran landslide, captioned a suggestion to pray for and help Pangandaran to lighten the people's burden. It does not mention concrete activities to do, but invitation to help might refer to civic activities of community problem solving.

- October 10 post of a screenshot news in foreign media on Ridwan Kamil partnership with crow-funding site kitabisa.com to raise USD350k for Rohingya victims. This news described Ridwan Kamil's effort in inviting his followers to donate for the Rohingyas through crowd-funding site, therefore it is an example of encouragement for fund-raising.

- There are several posts about policies of the mayor that aims to improve the well-being and happiness of the residents that seems like community problem solving, such as mobile consultant Kekasih, mobile medical service (Layad Rawat), which are ground-breaking. However, it is not said that the officers in the program are volunteers. It is more likely that they are paid for the job. However, the never-seen-before services for the residents can be seen as civic engagement because it aims at solving problems in the community that were often overlooked by other regional leaders for other more "concrete facilities" such as economic and education facilities.

From 18 tweets by ex-president SBY, there are two that are considered encouragement and example of civic engagement:

- August 14 post directed at Pramuka boy scout member to be proud of being boy scout and the part of Indonesia's golden generation, a term he invented to describe the future Indonesia where in 2045 the workforce population will double the non-workforce. This post implicitly encouraged a membership in Pramuka that is a non-formal organization with mostly outdoor social activities to build good character.

- Oct 26 post about a meeting between Democratic Party members with the Interior Minister and Communication and Information Minister, where the party suggested the revision of the social organization act Perppu Ormas. This indicates, as SBY and his Democratic Part are now the neutral side in politics, an example of contacting officials to express an opinion about an issue.

Therefore, among the 93 posts of the three politicians' social media posts, we found fourteen that include messages of civic engagement, six explicitly — as an invitation to a social event - and eight implicitly — as an example for civic engagement activities. The messages include at least an invitation, an encouragement, and an example for the individuals and groups to engage in civic activities to create a better life for all.

Explicit civic engagement invitations dominate Ridwan Kamil's Instagram posts; five out of seven. Meanwhile, Prabowo only has one explicit invitation to civic engagement from five posts, while SBY only has implicit example of civic engagement. Prabowo and SBY's lack of invitation to concrete civic activities in their post shows their visionary characteristic as leaders and politicians. Meanwhile, Ridwan Kamil's invitation to detailed and concrete civic activities indicate his architectural or technocratic background. Moreover, the 
national level of Prabowo and SBY's leadership is possibly one of the factors they don't focus on detail events and participation. However, Ridwan Kamil's invitation does not focus merely on local issues but also international ones such as the Rohingya crisis.

Politicians' posts about social activities and political participation is as much expected as their political messages for their constituents and potential voters. As most internet users do, politicians are more active in their social media and can focus on their intended public identity since they will not be filtered by the mainstream media. This means that politicians also feel more connected to the community as argued by Zúñiga, et al.'s research about how social network sites increases users' feel of connectedness to the community. They can reach their constituents and potential voters online, even communicate if they want to. Positive messages, particularly those that are not usually picked by the mainstream media, certainly fill their social media accounts as a form of campaign.

Political campaigns in Indonesia are dominated by invitation to "support", which means to vote for certain candidates by active support such as canvassing. However, very little focus on encouragement in civic activities which is of more concrete actions for direct contribution for the better of the societies. The only concrete actions suggested is to vote for a candidate. Other civic activities are seldom discussed although Prabowo, for example, engages in many social organizations. As SBY does, he mostly encouraged good deeds in general description such as to develop good characters for the nation, while SBY encouraged about working hard. The messages in politicians' social media posts show that Indonesia's politicians have not maximize their position to invite the citizens to engage in civic activities, although Indonesia is not unfamiliar with civic engagement, both offline and online, as found by Warren [19] and Lussier and Fish [20].

Another point to stress is the lack of "personalization" of those politicians in delivering their civic engagement messages. As Mazzoleni points out, the individual experience of leaders makes the public feel more connected to their own experience, therefore prompting the public to act [27]. Although the personalization of politics is used by Obama's digital campaign $[23,24]$ - which is the inspiration of SBY's Twitter account and tweeting styles as well as Ridwan Kamil's online activism - the two and Prabowo rarely exploit their personal experience to make connection with the public at large to deliver their civic engagement messages. Prabowo and SBY's show of activism examples never tells stories of their personal experience that can connect to people, while Ridwan Kamil's posts, although consist of a considerable number of personal life stories, rarely connect with his civic engagement messages. The connection between leaders' personal points of view and civic engagement should be considered to successfully ecourage civic engagement. This also means that there are rooms for improvement to boost civic engagement, both offline and online, in Indonesia.

\section{CONCLUSION}

The revealed few politicians' posts on civic engagement. This leads to the conclusion of minimal politicians' leadership in civic engagement through social media. However, there are proofs that Indonesians' civic engagement is abundant, with or without politicians' encouragement. There are several ways this research can be improved; (1) analyse social media posts from more politicians, particularly provincial and municipal leaders, since their job requires closer look to the society; (2) analyse comments and reactions from their followers to reveal the effectivities of the messages; (3) include non-political public figures' role in encouraging civic engagement, since they usually reach larger audiences.

\section{ACKNOWLEDGEMENTS}

This article is part of a research funded by PNBP Universitas Negeri Padang.

\section{REFERENCES}

[1] Alimuddin, A. and Seniwati, The Internet and Social Media in Political Participation in Indonesia. International Journal of Management and Applied Science, 2(8), pp. 95-97. 2016.

[2] Ognyanova, K. Online Participation in a Community Context: Online Participation in a Community Context:. International Journal of Communication, Volume 7, pp. 2433-2456. 2013.

[3] Gil de Zúñiga, H., Jung, N. and Valenzuela, S., Social Media Use for News and Individuals' Social Capital, Civic Engagement and Politica Participation. Journal of Computer-Mediated Communication, Volume 17, p. 319-336. 2012.

[4] Mihailidis, P., New Civic Voices and the Emerging Media Literacy Landscape. Journal of Media Literacy Education, 3(1), pp. 4-5. 2011.

[5] Bennett, W. L. and Segerberg, A., The Logic of Connective Action. Information, Communication and Society, 15(5), pp. 739-768. 2012.

[6] Dewantara, R. W. and Widhyharto, D. S., Aktivisme dan Kesukarelawanan dalam Media Sosial Komunitas Kaum Muda Yogyakarta. Jurnal Ilmu Sosial dan Ilmu Politik, 19(1), pp. 40-52. 2015.

[7] Johansson, A. C., Social Media and Politics in Indonesia, Stockholm: Stockholm School of Economics Asia Working Paper. 2016.

[8] Obar, J. A. and Wildman, S., Social media definition and the governance challenge: An introduction to the special issue. Telecommunications Policy, 39(9), pp. 745-750. 2015.

[9] boyd, d. and Ellison, N. B., Social Network Sites: Definition, History, and Scholarship. Journal of Computer-Mediated Communication, 13(1), pp. 210-230. 2007.

[10] Fuchs, C., Social Media: A Critical Introduction. London: Sage Publications Ltd. 2014.

[11] Katz, J. E., Barris, M. and Jain, A., The Social Media President: Barack Obama and the Politics of Digital Engagement. 1 ed. New York: Palgrave Macmillan. 2013.

[12] Putnam, R., Bowling Alone. Journal of Democracy, pp. 65-78. 1995.

[13] Anon., American Psychological Association. [Online] Available at: http://www.apa.org/education/undergrad/civic-engagement.aspx [Accessed 25 February]. 2018.

[14] Banyan, M. E., Encyclopaedia Britannica. [Online] Available at: https://www.britannica.com/topic/civic-engagement [Accessed 25 February]. 2018

[15] Adler P. and Goggin, J., What Do We Mean By "Civic Engagement"? Journal of Transformative Education, 3(3), pp. 236-253. 2005.

[16] Ehrlich, T., Civic Responsibility and Higher Education. Westport: Oryx Press. 2000.

[17] Verba, S., Schlozman, K. L. and Brady, H., Voice and Equality: Civic Voluntarism in American Politics. Massachusetts: Harvard University Press. 1995 
[18] Keeter, S., Zukin, C., Andolina, M. and Jenkins, K., The Civic and Political Health of the Nation: A Generational Portrait, s.1.: The Center for Information and Research on Civic Learning and Engagement. 2002.

[19] Warren, A. M., Jafaar, N. I. and Sulaiman, A., Youth Civic Engagement Behavior on Facebook: A Comparison of Findings from Malaysia and Indonesia. Journal of Global Information Technology Management, 19(2), pp. 128-142. 2016.

[20] Lussier, D. N. and Fish, M. S., Indonesia: The Benefits of Civic Engagement. Journal of Democracy, 23(1), pp. 70-84. 2012.

[21] Chang, W.-Y., Online Civic Participation, and Political Empowerment: Online Media and Public Opinion Formation in Korea. Media Culture Society, 27(6), pp. 925-935. 2005.

[22] Dimitrova, D. V., Shehata, A., Strömbäck, J. and Nord, L. W., The Effects of Digital Media on Political Knowledge and Participation in Election Campaigns: Evidence From Panel Data. Communication Research, XX(X), pp. 1-24. 2011.

[23] Cogburn, D. L. and Espinoza-Vasquez, F. K., From Networked Nominee to Networked Nation: Examining the Impact of Web 2.0 and
Social Media on Political Participation and Civic Engagement in the 2008 Obama Campaign. Journal of Political Marketing, 10(1-2), pp. 189-213. 2011.

[24] Gerodimos, R. and Justinussen, J., Obama's 2012 Facebook Campaign: Political Communication in the Age of the Like Button. Journal of Information Technology and Politics, 12(2), pp. 113-132. 2015.

[25] Bimber, B., Digital Media in the Obama Campaigns of 2008 and 2012: Adaptation to the Personalized Political Communication Environment. Journal of Information Technology and Politics, 11(2), pp. 130-150. 2014.

[26] Balmas, M. and Sheafer, T., Personalization of Politics. [Online] Available at: http://onlinelibrary.wiley.com/doi/10.1002/9781118541555.wbiepc021/f ull [Accessed 1 8]. 2016.

[27] Mazzoleni, G., A Return to Civic and Political Engagement Prompted by Personalized Political Leadership. Political Communication, , 17(4), pp. 325-328. 2000. 